\title{
MEMBACA METODE PENAFSIRAN AL-QUR'AN KONTEMPORER DI KALANGAN SARJANA BARAT ANALISIS PEMIKIRAN ANGELIKA NEUWIRTH
}

\author{
Lien Iffah Naf'atu Fina \\ (STAI Sunan Pandanaran Yogyakarta \\ email: zuhdi_ibu@yahoo.co.id)
}

Abstract: This article examines Western scholar thoughts on methods of Qur'anic exegesis. It specifically analyzes Angelike Neuwirth's thoughts as one of the leading western scholars on the Qur'an. She is considered the pioneer of academic-dialogic approaches to the Qur'an. She offers reading the Qur'an from the period of pre-canonization to conceive of the ways in which the Qur'an in the time of its revelation interacted with its surroundings. To understand this, she looks at relevant united verses as an integral unit that keeps important processes of communication during the lifetime of the Prophet. She concludes that these types of the verses are represented by the Meccan verses, not all verses of the Qur'an. Her study provides a new path in contemporary Qur'anic studies especially in the efforts to "revive" the codified Qur'an.

Abstrak: Artikel ini mengulas bagaimana metode tafsir yang ditawarkan oleh kesarjanaan Barat kontemporer. Fokus pandang yang diambil di sini adalah Angelika Neuwirth, seorang sarjana Barat yang sangat serius menekuni al-Qur'an dan diakui sebagai pionir kajian sarjana Barat yang bersifat akademis-dialogis. Neuwirth menawarkan pembacaan prakanonisasi al-Qur'an yang berupaya menggali bagaimana sepak terjang alQur'an pada masa labirnya dengan berpijak kepada satuan surat yang dianggapnya sebagai satuan unit integral dan menyimpan proses komunikasi pada masa Nabi. Kajian Neuwirth ini memberikan warna lain dalam kesarjanaan al-Qur'an kontemporer, terutama dalam upaya untuk 'menghidupkan kembali' al-Qur'an kodifikasi.

Keywords: surat, struktur mikero teks, makiyah, madaniyah, kodifikasi al-Qur'an, prakanonisasi, dehistorisasi. 
STUDI metode tafsir al-Qur'an adalah studi yang tidak pernah mati karena fakta sejarah membuktikan bahwa setiap masa menghasilkan cara mendekati al-Qur'an yang unik dan berbedabeda sesuai dengan konteks ruang dan waktu. Sejarah juga menunjukkan bahwa aktor yang turut terlibat dalam dinamika studi al-Qur'an bukan saja dari kalangan Muslim (insider), tetapi juga dari outsider. Tentang yang terakhir, telah banyak tulisan yang merekam bagaimana persinggungan antara dua kesarjanaan ini dalam kajian al-Qur'an.

Tulisan ini adalah sebuah upaya untuk memotret perkembangan tafsir kontemporer di kalangan sarjana Barat dengan mengkaji salah seorang di antaranya, yaitu Angelika Neuwirth. Lewat karyanya yang banyak dan serius, Neuwirth memberikan sumbangan yang besar dalam studi al-Qur'an di Barat. Dia juga dianggap sebagai peletak kecenderungan dialogisakademis dalam kesarjanaan al-Qur'an di Barat. Fokus tulisan ini adalah pada metode analisis al-Qur'an yang ditawarkan olehnya. Dari situ, tulisan ini diharapkan mampu menyuguhkan metode tafsir sarjana Barat kontemporer dalam ruang diskusi kesarjanaan al-Qur'an di Indonesia.

\section{Kesarjanaan Barat Kontemporer, Angelika Neuwirth, dan Corpus Coranicum}

Sejarah kesarjanaan al-Qur'an di Barat sangat panjang sejak zaman Nabi sampai kontemporer dengan dinamika dan konteks masing-masing. Pada masa kontemporer, paling tidak sejak tahun 1980, kesarjanaan al-Qur'an di Barat menemukan spiritnya yang lebih dialogis dan akademis ketimbang skeptis, apologetik, dan polemis seperti sebelum-sebelumnya. Yang memungkinkan itu terjadi adalah karena mulai digunakannya pendekatan sastra terhadap al-Qur'an. Boullata, dan McAuliffe, misalnya, telah melakukan kritik atas paradigma para pendahulu mereka. Mereka, dengan ungkapan yang senada, menyatakan bahwa kajian al-Qur'an kontemporer sudah tidak masanya lagi mempertanyakan orisinalitas dan historisitasnya. Sebaliknya, studi al-Qur'an seharusnya diarahkan kepada teks yang ada di tangan kita sekarang, mengkajinya sebagai sebuah teks sastra dan 
karenanya didekati dengan pendekatan sastra. ${ }^{1}$ Dalam bahasa Abu Zayd, bergeser dari paradigma "the genesis of the Qur'an to the paradigm of textus receptus'. Sebagai buah kecenderungan baru ini, muncul beberapa karya bersama sarjana Muslim dan Barat tentang kajian al-Qur'an. ${ }^{3}$

Dalam pergeseran ini, para sarjana di atas mendaku Angelika Neuwirth sebagai sarjana Barat pertama dalam pendekatan ini, lebih khusus lagi tentang pendekatan berbasis surat, terutama

'Lihat, Stefan Wild, "Preface", dalam Stefan Wild, The Qur'an as Text (London: E. J. Brill, 1996), viii-ix; Issa J. Boullata, "Introduction" dalam Literary Stuctures of Religious Meaning in the Qur'an, ed. Issa J. Boullata (Richmond: Curzon Press, 2000), ix-xii. Bandingkan dengan Jane Dammen McAuliffe, "Preface", dalam Encyclopaedia of the Qur'an, volume 1, ed. Jane D. McAuliffe (Leiden: E. J. Brill, 2001), iii.

${ }^{2}$ Nasr Hamid Abu Zayd, Rethinking the Qur'an: Towards a Humanistic Hermeneutics (Amsterdam: Humanistics University Press, 2004), 10.

${ }^{3}$ Salah satu hal signifikan yang menandai kecenderungan ini adalah terbitnya beberapa buku antologi bersama sarjana Barat dan Muslim. Terbitnya buku-buku ini menunjukkan telah adanya keterbukaan untuk berdialog ketimbang berdebat, dan karenanya lebih bersifat akademis. Buku tersebut misalnya, Andrew Rippin (ed.), Approaches to the History of the Interpretation of the Qur'an (Oxford: Clarendon Press, 1988); G. R. Hawting dan Abdul-Kader A. Shareef (ed.), Approaches to the Qur'an (London dan New York: Routledge, 1993); Stefan Wild (ed.), The Qur'an as Text (London: E. J. Brill, 1996); Issa J. Boullata (ed.), Literary Stuctures of Religious Meaning in the Qur'an (Richmond: Curzon Press, 2000); Jane D. McAuliffe (ed.), Encyclopaedia of the Qur'an, volume 1-5 (Leiden: E. J. Brill, 2000-2006); Jane Dammen McAuliffe (ed.), The Cambridge Companion to the Qur'an (Cambridge: Cambridge University Press, 2006); Andrew Rippin (ed.), The Blackwell Companion to the Qur'an (Oxford: Blackwell Publishing, 2006); Angelika Neuwirth, Nicolai Sinai dan Michael Marx (ed.), The Qur'an in Context: Historical and Literary Investigations into the Qur'anic Milieu (London: E. J. Brill, 2010), dan jurnal berkala yang terbit sejak tahun 1998 hingga sekarang, Journal of Qur'anic Studies. Bersama kecenderungan baru ini, bukan berarti pendekatan yang polemis terhadap al-Qur'an sama sekali hilang. Fakta ini bisa dilihat pada, misalnya karya Cristopher Luxenberg, Die Syro-Aramaische Lesart des Koran: eine Entschlusseng der Koransprache (Berlin: Das Arabische Buch, 2000). Namun, karena sedikitnya fenomena demikian, bahkan sarjana Barat sendiri pun banyak yang mengkritik paradigma ini, kajian akademis dan dialogis tetaplah menjadi aksentuasi dari masa-masa ini. Tentang kritik terhadap Luxenberg, lihat, Angelika Neuwirth, "Orientalism in Oriental Studies?: Qur'anic Studies in Case" dalam Journal of Qur'anic Studies, volume IX, Issue 2 (2007), 120-2. 
lewat disertasinya yang diterbitkan menjadi buku pada tahun 1981, Studien Zur Komposition Der Mekkanischen Suren: Die Literarische Form Des Koran. ${ }^{4}$

Angelika Neuwirth ${ }^{5}$ adalah seorang sarjana Barat Yahudi yang lahir di Nienburg/Weser pada tanggal 4 November 1943. Spesialisasi dan ketertarikan Neuwirth adalah pada bidang sastra Arab klasik dan modern. Baru belakangan dia fokus kepada studi al-Qur'an. Karenanya tak heran jika pendekatannya kepada alQur'an sangat kental aroma sastranya.

Ketertarikan yang serius Neuwirth kepada al-Qur'an bermula sejak dia menulis disertasi di atas. Dalam disertasi ini, Neuwirth 'melanjutkan' kerja Noldeke dengan menganalisis struktur surat-surat Makkiyah dengan menggunakan pendekatan sastra yang sangat ketat. ${ }^{6}$ Pada masa berikutnya, ada pergeseran

${ }^{4}$ Lihat, misalnya, Stefan Wild, "Preface", ix; Boullata, "Literary Structures of the Qur'an" dalam Encyclopaedia of the Qur'an, volume 3, ed. Jane D. McAuliffe (Leiden: E. J. Brill, 2003), 196; Neal Robinson, Discovering the Qur'an: a Contemporary Approaches to a Veiled Text (London: SCM Press, 1996), 2; Daniel A. Madigan, The Qur'an's Self-Image: Writing and Authority in Islam's Scripture (Princeton dan Oxford: Princeton University Press, 2001), 87.

${ }^{5}$ Neuwirth belajar studi agama Yahudi, sastra Arab dan filologi klasik di Universitas Teheran dilanjutkan belajar bahasa-bahasa Semit dan Arab di Universitas Gottingen (1964-1967). Studi Master ditempuhnya di Hebrew University di Jerusalem (1967-1970). Neuwirth menyelesaikan program doktoralnya dalam Semitic Studies di University of Gottingen pada tahun 1972 dan melanjutkan program postdoktoral di Universitas Munich. Selepasnya dia mengajar di beberapa tempat dan sejak tahun 1991, menjadi Professor sastra Arab di Freie University Berlin. Biografi ini penulis sarikan dari berbagai sumber. Lihat, http://www.ias. edu/news/pressreleases/1243342965, akses tanggal 8 oktober 2010; http://journal.oraltradition.org/authors/show/553, akses tanggal 23 Oktober 2010; http://www2.huberlin.de/gkgeschlecht/okzidentalismus/abstr_sa_en. php, akses tanggal 23 Oktober 2010; http://en.wikipedia.org/wiki/Angelika_Neuwirth, akses tanggal 18 Juni 2011; Aetik Romazona, “Canonical Text”,18-49.

'Informasi tentang isi buku Neuwirth ini penulis dapatkan dari reviu yang ditulis oleh Andrew Rippin dan diterbitkan dalam Bulletin of the School of Oriental and African Studies, volume 45, number 1 (1982), 149-50. Gagasan Neuwirth yang dituangkan dalam buku ini, meski diakuinya ada beberapa hal yang perlu direvisi, masih digunakan hingga sekarang. Bahkan, 
yang signifikan dalam pemikiran Neuwirth, khususnya dalam cakupan studi al-Qur'an. Babak ini merupakan momen di mana dia telah melampaui paradigma strukturalis murni dengan beranjak kepada aspek sejarah sebagaimana dibenarkan oleh Neal Robinson. Artinya di titik ini, Neuwirth telah memadukan pendekatan sastra dengan historis. Pergeseran ini, menurut Robinson, setidaknya dapat ditangkap dari diterbitkannya sebuah artikel Neuwirth yang berjudul "Von Rezitationstext uber die liturgie zum Kanon: Zu Entstehung und Wiederauflosung der Surenkomposition im Verlauf der Entwicklung eines Islamischen Kultus" pada tahun 1996.8

Sejak tahun 1990-an, Neuwirth semakin produktif melahirkan karya dalam bidang al-Qur'an dalam berbagai bahasa. ${ }^{9}$ Bahkan Neuwirth membentuk Corpus Coranicum, sebuah proyek yanag bertujuan untuk melahirkan pemahaman kontekstual terhadap al-Qur'an yang lebih baik bagi masyarakat Barat. Tujuan ini terfokus dalam tiga agenda besar. Pertama, membuat dokumentasi manuskrip-manuskrip al-Qur'an awal beserta variasi qirā'āt. Kedua, melakukan penelitian dan kajian serta membuat bank data Texte aus der Welt des Quran (teks-teks di sekitar al-Quran). Ketiga, menghasilkan interpretasi dengan pendekatan historis kritis dan sastra terhadap al-Qur'an (der historisch-kritische literaturwissenschaftliche Kommentar des Quran). ${ }^{10} \mathrm{Di}$

perkembangan pemikiran Neuwirth pada masa belakangan sangat 'berhutang' kepada disertasinya ini.

${ }^{7}$ Angelika Neuwirth, "Von Rezitationstext uber die liturgie zum Kanon: $\mathrm{Zu}$ Entstehung und Wiederauflosung der Surenkomposition im Verlauf der Entwicklung eines Islamischen Kultus" dalam The Qur'an as Text, ed. Stefan Wild (London: E. J. Brill, 1996), 69-105.

${ }^{8}$ Neal Robinson, "The Structure and Interpretation of Surat alMukminun", Journal of Qur'anic Studies, volume II, Issue I (2000), 104.

'Untuk karya-karya Neuwirth selengkapnya, lihat, Lien Iffah Na'atu Fina, Pre-Canonical Reading of the Qur'an: Studi atas Metode Angelika Neunirth dalam Analisis Teks al-Qur'an Berbasis Surat dan Intertekstualitas, Thesis (Yogyakarta: PPs UIN Sunan Kalijaga, 2011), 88-90.

${ }^{10}$ Lihat http://en.wikipedia.org/wiki/Corpus_Coranicum, akses tanggal 23 Oktober 2010; Bandingkan dengan hasil wawancara dengan Corpus Coranicum pada Juli 2010 yang direkam dalam Sahiron Syamsuddin, "Studi alQur'an di Jerman", Republika, 17 September 2010. 
antara ketiga agenda ini, pembahasan dalam tulisan ini lebih terkait dengan fokus ketiga.

Untuk meluluskan agenda tersebut, selain melakukan riset, Corpus Coranicum juga menggelar beberapa konferensi internasional, terlibat dalam berbagai konferensi internasional dan menerbitkan buku yang mengangkat tema seputar pendekatan historis-sastra terhadap al-Qur'an. Buku-buku rujukan tersebut adalah buku antologi Im vollen Licht der Geschichte: Die Wissenchaft des Judentums und die Anfange de kritischen Koranforchung (2008), The Qur'an in Context. historical and literary investigations into the Qur'anic milieu (2010),11 dan karya Neuwirth, Der Koran als Text der Spätantike. Ein europä̈scher Zugang (2010).

Apresiasi terhadap pemikiran Neuwirth beragam. Ada yang menyebut proyeknya sebagai kembalinya kesarjanaan Barat kepada penyelidikan dan pertanyaan historisitas al-Qur'an. Penulis tidak sepakat dengan anggapan ini. Neuwirth sendiri memberikan kritik yang tajam kepada kesarjanaan Barat terutama terkait kesimpulan mereka akan komposisi al-Qur'an yang mereka anggap tidak sistematis, acak, dan serangkaian label negatif lain. Dia juga mengkritik anggapan bahwa al-Qur'an merupakan jiplakan dari kitab terdahulu. Kesimpulan kajian Neuwirth secara tegas menegasikan dua kesimpulan di atas. Historisitas yang diancangkan Neuwirth tidaklah terjerembab pada pertanyaan asal-usul sebagaimana dikritik Wild, Boullata dan Abu Zayd di atas, tapi historisitas yang lebih mendalam dalam rangka menggali konteks al-Qur'an.

\section{Pembacaan Pra-Kanonisasi al-Qur'an: Analisis Struktur Mikro Teks dengan Pendekatan Sastra-Sejarah}

Titik berangkat pemikiran Neuwirth adalah pada konsepsinya tentang al-Qur'an pra-kanonisasi (canon from below)

${ }^{11}$ Angelika Neuwirth, Nicolai Sinai, dan Michael Marx (ed.),The Qur'än in Context: Historical and Literary Investigations into the Qur'anic Milieu (Leiden: Brill, 2010). Dalam pendahuluan, Neuwirth dan Sinai mengatakan bahwa pemilihan judul buku The Qur'an as Context adalah secara sadar untuk menyandingkan dengan karya Stefan Wild (ed.), The Qur'an as Text yang terbit tahun 1996. 
dan post-kanonisasi (canon from above). ${ }^{12}$ Yang pertama adalah alQur'an yang hidup pada masa Nabi, dan yang kedua adalah alQur'an yang telah dikodifikasi oleh para redaktur al-Qur'an hingga dalam bentuknya yang ada sekarang. Meskipun kanonisasi teks adalah sebuah keniscayaan, Neuwirth menekankan beberapa implikasi dari proses ini dalam al-Qur'an. Pertama, tercerabutnya al-Qur'an dari konteks sejarah lahirnya. Al-Qur'an yang semula merupakan komunikasi horizontal menjadi vertikal dan linier (antara reader dan Tuhan) setelah kanonisasi. ${ }^{13}$ Kedua, unit surat yang semula menjadi satuan unit komunikasi menjadi kabur ketika dia disejajarkan dengan yang lain. ${ }^{14}$ Ketiga, kaburnya karakter bahwa al-Qur'an lahir secara berangsur-angsur. ${ }^{15}$ Singkatnya, kanonisasi telah menjadikan alQur'an terdehistorisasi. Ketika al-Qur'an telah berbentuk seperti sekarang, yang menonjol bukan lagi karakter menyejarahnya sebagaimana dia dahulu hadir di tengah-tengah bangsa Arab, tetapi karakter timeless, eternal ataupun beyond history-nya. ${ }^{16}$ Padahal menurut Neuwirth, gagasan beyond history al-Qur'an sebenarnya sangat bertentangan dengan karakter oral yang inhern dalam alQur'an yang menunjukkan bahwa al-Qur'an sebenarnya lahir dari sebuah proses komunikasi dengan karakter drama yang kental. ${ }^{17}$

${ }^{12}$ Mengikuti teori Aleida dan Jassmann. Lihat, Angelika Neuwirth. "Referentiality and Textuality in Surat al-Hijr: Some Observations on the Qur'anic "Canonical process" and the Emergence of a Community" dalam Literary Stuctures of Religious Meaning in the Qur'an. ed. Issa J. Boullata (Richmond: Curzon Press, 2000), 146.

${ }^{13}$ Angelika Neuwirth, "Structure and the Emergence of Community" dalam The Blackwell Companion to the Qur'an. ed. Andrew Rippin (Oxford: Blackwell Publishing, 2006), 146. Bandingkan, Nasr Hamid Abu Zayd, Rethinking the Qur'an: Towards a Humanistic Hermeneutics (Amsterdam: Humanistics University Press, 2004), 7.

${ }^{14}$ Angelika Neuwirth, "Qur'an and History - a Disputed Relationship: Some Reflections on Qur'anic History in the Qur'an", Journal of Qur'anic Studies, volume 3 (2003), 11.

15Neuwirth, "Referentiality and Textuality...", 143.

${ }^{16}$ Ibid., 145.

${ }^{17}$ Beberapa karakter oral ini bisa dilihat dalam pernyataan dirinya sebagai teks yang dibaca. Angelika Neuwirth, "Rhetoric and the Qur'an" dalam Encyclopaedia of the Qur'an, volume 4. ed. Jane D. McAuliffe (Leiden: E. 
Untuk mencerahkan persoalan ini, Neuwirth menawarkan gagasan untuk membaca teks yang ada sekarang ini (mushaf Usmani) dengan pembacaan pra-kanonisasi, pre-canonical reading of the Qur'an, yakni pembacaan al-Qur'an sebagai canon from below ketika dia masih berada dalam kerangka a process of growth, atau pembacaan yang "presenting lively scenes from the emergence of community". 18 Pembacaan yang dilakukan Neuwirth ini, dengan demikian, masuk ke dalam upaya pencarian original meaning, what really happened atau pre-canonical text dari al-Qur'an dalam pengertian penelusuran konteks historisnya, bukan mencari 'teks asli'nya seperti umumnya para sarjana Barat (Urtext). ${ }^{19}$

Menurut Neuwirth, teks al-Qur'an adalah teks yang isi, gaya bahasa, struktur, dan retorikanya berkembang disesuaikan dengan situasi yang melatarinya. ${ }^{20}$ Ketika kesemuanya berubah, al-Qur'an juga akan dengan lentur menyesuaikan dirinya demi efektivitas penyampaian pesannya. Perkembangan struktur dan isi dalam internal satuan unit surat ini karenanya bisa menjadi jalan untuk merangkai al-Qur'an pra-kanonisasi karena di sana ada 'informasi' tentang di mana, kapan, bagaimana, dan siapa yang terlibat dalam komunikasi tersebut.

Untuk tujuan ini, Neuwirth mendasarkan analisisnya pada surat. Mengapa Neuwirth menggunakan surat sebagai pijakan analisisnya? Ia menyakini bahwa surat adalah satuan unit yang menyimpan proses komunikasi pada masa kelahirannya sekaligus

J. Brill, 2004), 470. Selain itu, bisa juga dilihat dalam cara al-Qur'an menuturkan dirinya. Lihat, Mustansir Mir, "Language" dalam The Blackwell Companion to the Qur'an, ed. Andrew Rippin (Oxford: Blackwell Publishing, 2006), 93-4.

${ }^{18}$ Neuwirth, "Qur'an and History...", 6.

${ }^{19}$ Angelika Neuwirth, "Form and Structure of the Qur'an" dalam Encyclopaedia of the Qur'an, volume 2, ed. Jane D. McAuliffe (Leiden: E. J. Brill, 2002), 253.

${ }^{20}$ Neuwirth menyebut ini dengan adanya kesinambungan antara the growth of corpus dan the emergence of community. Selain itu, ada fenomena referensialitas (dari teks belakangan kepada teks yang mendahuluinya) dalam al-Qur'an yang bisa digunakan untuk mengetahui tahapan perkembangan wahyu. Neuwirth, "Referentiality and Textuality...", 147; Neuwirth, "Form and Structure...", 249. Secara singkat, apa yang disebutkan Neuwirth ini senada dengan teori kesarjanaan Muslim tentang surat Mekkah dan Madinah. 
sebagai unit integral yang terjamin secara redaksionalnya sebagai teks sastra. ${ }^{21}$ Pada masa lahirnya, surat adalah unit teks yang dibaca di hadapan audiens untuk kemudian menjadi teks liturgi komunitas Nabi. Aspek liturgical and cultic (and communal) function of the text ini merupakan tesis sentral bagi pemikiran Neuwirth tentang surat. ${ }^{22}$

Cara Neuwirth untuk menghidupkan surat yang ada dalam al-Qur'an post-kanonisasi sehingga keluar karakter prakanonisasinya ini adalah dengan melakukan analisis struktur mikro terhadap satuan surat. ${ }^{23}$ Langkah kerjanya adalah: pertama (langkah riilnya akan penulis sampaikan di bawah), mengkaji sebuah surat sebagai satuan pericope atau quranun yakni unit tuturan yang membincangkan fokus pesan tertentu dan menghasilkan kesan tertentu kepada pendengar. Selain mengkaji al-Qur'an sebagai pericope, juga mengkajinya sebagai teks liturgi. Sebagai teks liturgi, satuan surat memiliki kapasitas untuk mengguncangkan kesadaran, ingatan, dan pengetahuan para pendengarnya terhadap text nucleus ('context') yakni teks-teks yang telah hadir lebih dulu, dan realitas yang ada di luar teks. ${ }^{24}$

Karakter terakhir ini yang dimanfaatkan Neuwirth dalam mengkaji surat yang disebutnya sebagai karakter referensial. Referentiality yang pada proses lahirnya al-Qur'an berfungsi sebagai pemenuhan fungsi komunikasi dan retorika ini, untuk menggetarkan dan mengundang perenungan kepada para pendengarnya, bisa dimanfaatkan untuk melakukan analisis teks tertulis yang 'tampak beku' sekarang ini. Menafsirkan apa yang

${ }^{21}$ Ibid., 246.

${ }^{22}$ Tesis Neuwirth ini dibahas panjang lebar dalam artikelnya "Von Rezitationstext uber die liturgie zum Kanon: $\mathrm{Zu}$ Entstehung und Wiederauflosung der Surenkomposition im Verlauf der Entwicklung eines Islamischen Kultus" dalam Stefan Wild, The Qur'an as Text (London: E. J. Brill, 1996).

23Perlu digaris bawahi bahwa kesimpulan Neuwirth tentang surat ini berlaku untuk surat Makkiyah mengingat fokus pertama kajiannya adalah pada surat-surat periode ini. Dengan kata lain, kata "surat" yang penulis gunakan berikutnya merujuk utamanya kepada surat-surat Makkiyah, bukan keseluruhan surat dalam al-Qur'an. Kesimpulan Neuwirth tentang surat Madaniyah sedikit berbeda yang penjelasannya tidak mungkin dicakup oleh tulisan ini.

${ }^{24}$ Neuwirth, "Referentiality and Textuality"..., 147. 
disampaikan Neuwirth, penulis melihat ada tiga aspek referentiality. ${ }^{25}$ Pertama, kepada teks di dalam surat untuk membangun kepaduan surat. Kedua, kepada nucleus text dari surat tertentu ${ }^{26}$ yang bisa dimanfaatkan untuk membangun informasi tentang posisi surat tertentu dalam perkembangan wahyu. Suratsurat yang menjadi 'tempat bersandar' surat ini sebagai surat yang lebih awal, dan surat-surat yang mengandung materi yang bergantung kepada surat ini sebagai surat yang lebih akhir dari surat ini. ${ }^{27}$ Ketiga, terhadap realitas di luar teks-penelusuran ini dibantu oleh data sejarah. ${ }^{28}$

Pada yang ketiga inilah kemudian masuk kajian intertekstualitas Neuwirth, ${ }^{29}$ yakni, mengkaji surat dan melibatkannya dengan teks-teks yang dianggap mengitari alQur'an pada masa itu, yang disebut Neuwirth masuk dalam masa

25Pemilahan ini adalah murni tafsir penulis terhadap gagasan Neuwirth. Neuwirth tidak pernah menyebutkan pemilahan ini secara eksplisit. Lihat, Ibid., 152-3. Pendapat penulis ini didukung oleh ungkapan Sinai tentang processual reading, yakni “...to take into account not only a given surab's link to its bistorical context of origin but also its link to the corpus of already existing revelations in order to bring to light any possible intra-qur'anic interpretive role it might have". Lihat, Nicolai Sinai, “The Qur'an as Process...”, 438.

${ }^{26}$ Dalam dua kesempatan yang berbeda, Neuwirth merujukkan dua istilah yang berbeda untuk kategori ini. Pertama, Neuwirth menggambarkan analisis ini sebagai intratekstualitas, "...the intratextual discussion about the process of growth", lihat, Neuwirth, "Referentiality and Textuality...", 159. Kedua, intertekstualitas. Hal ini tampak dalam pernyataan Neuwirth, "...They will then be discussed as to their intertextual relationship to their wider context, i. e. already existing earlier texts (canonical nucleus)". Lihat, Angelika Neuwirth, "Negotiating Justice: A pre-Canonical Reading of the Qur'anic Creation Accounts-Part I", Journal of Qur'anic Studies, volume II, Issue I, (2000), 30. Dalam hemat penulis, peristilahan yang berbeda ini sama sekali tidak bertentangan. Yang pertama mengandaikan al-Qur'an sebagai satu teks sedangkan yang kedua mengandaikan surat sebagai satu unit teks, sehingga surat-surat lain sebagai teks-teks yang lain.

${ }^{27}$ Neuwirth, "Referentiality and Textuality...., 160.

${ }^{28}$ Neuwirth, "Negotiating Justice...", 30; Neuwirth, "Referentiality and Textuality...”, 152.

${ }^{29}$ Penelitian interteks Neuwirth bisa dilihat langsung dalam karyanya, misalnya "Qur'anic Reading of the Psalms" dalam The Qur'an in Context: Historical and Literary Investigations into the Qur'anic Milieu. ed. Angelika Neuwirth, Nicolai Sinai dan Michael Marx (London: E. J. Brill, 2010). 
Late Antiquity, ${ }^{30}$ antara lain kitab suci kaum Yahudi (Ibrani) dan Kristen (Aramaik), retorika Yunani dan puisi Arab. ${ }^{31}$ Neuwirth menegaskan, hal yang perlu diingat adalah bahwa pada mulanya al-Qur'an bukanlah kitab suci umat Islam, tetapi sebagai teks yang ditujukan kepada audien yang sangat beragam pada masa Late Antiquity. Karenanya, al-Qur'an haruslah dibaca bersama dengan teks-teks lain yang mengitarinya untuk mendapatkan gambaran yang lebih utuh tentangnya.

Bentuk konkret dari tahap pertama ini adalah dengan membagi surat ke dalam satu atau beberapa kelompok ayat berdasarkan grammatical structure of each segment dan the thematic contentnya, ${ }^{32}$ dalam bahasa Robinson berdasarkan form dan contentnya. Menurut Robinson, pergeseran tema dan rima atau ritme sangat mudah ditangkap oleh bangsa Arab yang memang

${ }^{30}$ Neuwirth serius melakukan penelitian dan menelusuri tradisi dan teks yang mengitari al-Qur'an. Salah satu buku yang didedikasikan oleh Neuwirth dan Corpus Coranicum untuk menjawab ini adalah The Qur'an in Context Historical and Literary Investigations into the Qur'anic Milieu (2010).

${ }^{31}$ Neuwirth, “The 'Late Antique Qur'an': Jewish-Christian Liturgy, Hellenic Rhetoric and Arabic Language", Public Lecture, 3 Juni 2009 di West Building Lecture Hall at the Institute for Advanced Study. www. ias. edu, akses tanggal 23 Oktober 2010.

${ }^{32}$ Neuwirth, "Form and Structure...", 251, dan 252; Andrew Rippin, "Book Review: Studien zur Komposition der Mekkanischen Suren by Angelika Neuwirth", Bulletin of the School of Oriental and African Studies, volume 45, number 1 (1982), 149. Model tafsir yang demikian, yakni menyingkap kepaduan surat dengan membangun antara kelompok-kelompok ayat dalam surat, bukanlah hal yang baru dalam kesarjanaan al-Qur'an. Banyak sarjana yang melahirkan karya tafsir berbasis surat ini sejak zaman klasik, modern dan kontemporer. Mir menyebutnya dengan Sura as Unity dan Suras as Unity, kesatuan dalam surat dan dalam al-Qur'an. Siapa sarjana yang menekuni kajian ini dan hasil kajian mereka, lihat keterangan selengkapnya dalam Mustansir Mir, Coherence in the Qur'an: A Study of Islähì's Concept of Nazm in Tadabbur-i Qur'an (Washington: American Trust Publications, 1986); "The Süra as a Unity: a Twentieth Century Development in Qur'an Exegesis" dalam G. R. Hawting dan Abdul-Kader A. Shareef, Approaches to the Qur'an (London and New York: Routlegde, 1993), 211-24. Untuk melihat rekonstruksi kajian berbasis surat dalam kesarjanaan Muslim dan Barat, lihat Lien Iffah, "Pre-Canonical Reading...", 21-58. Meskipun kajian ini jamak dilakukan sarjana al-Qur'an, penulis melihat perbedaan Neuwirth dengan model tafsir berbasis surat lain ini terletak pada semangat pembacaan prakanonisasi Neuwirth. Untuk selengkapnya lihat, Ibid., 196-200. 
terbiasa dengan hal ini, ${ }^{33}$ tidak sebaliknya bagi para pembaca alQur'an yang berbeda ruang dan waktu kelahirannya, apalagi setelah terjadinya kanonisasi. Karenanya, untuk kepentingan menyingkap bagaimana satuan surat tersebut menyampaikan pesannya, jejak-jejak pergeseran ini perlu dianalisis. Kelompokkelompok ayat dalam surat ini kemudian dianalisis dalam kerangka referensialitas di atas sehingga bisa direngkuh maksud pesan dalam satu surat tersebut, siapa saja aktor yang terlibat di dalamnya, dan posisi surat tersebut dalam perkembangan wahyu dan komunitas Nabi. ${ }^{34}$

Langkah kedua dari keseluruhan analisis struktur mikro, yang sesungguhnya menurut penulis adalah langkah yang berjalin-kelindan dengan yang pertama, adalah menghadirkan kembali historisitas al-Qur'an yang berpijak kepada sejarah Nabi. Dengan demikian, data-data sira, baik tentang Nabi atau yang lain yang mengitari pewahyuan al-Qur'an, menemukan manfaatnya. ${ }^{35}$ Tanpa data-data ini, analisis surat hanya berhenti pada analisis struktur yang mati. Sebaliknya, dengan data-data ini, satuan surat bisa dihidupkan dalam posisinya dalam proses pewahyuan dan lahirnya komunitas Nabi. Melalui model pembacaan al-Qur'an inilah Angelika Neuwirth menggabungkan pendekatan sastra dan sejarah dalam kajian al-Qur'an.

\section{Reposisi al-Qur'an}

Gagasan Neuwirth di atas bisa dianggap sebagai sebuah undangan untuk melakukan reposisi al-Qur'an. Sebenarnya, kegelisahan Neuwirth atas dehistorisasi al-Qur'an sejalan dengan kegelisahan para sarjana Muslim kontemporer, seperti al-Khulli, Arkoun, Fazlur Rahman dan Abu Zayd, akan akutnya pandangan Muslim terhadap sakralitas teks yang tidak

${ }^{33}$ Neal Robinson, Discovering the Qur'an: a Contemporary Approaches to a Veiled Text (London: SCM Press, 1996), 99.

${ }^{34}$ Hasil analisis Neuwirth terhadap satuan surat bisa dilihat dalam disertasinya dan beberapa tulisan berikut: "Referentiality and Textuality..."; "Images and Metaphors in the Introductory Section of the Meccan suras" dalam Approaches to the Qur'an, ed. G. R. Hawting dan Abdul-Kader A. Shareef (London dan New York: Routledge, 1993), 3-36.

${ }^{35}$ Neuwirth, "Referentiality and Textuality...", 1 dan 145. ; Nicolai Sinai, “The Qur'an as Process...”, 414-15. ; “Qur'an and History...”, 1. 
memberikan ruang sama sekali kepada reinterpretasi teks, bahkan sering melahirkan penafsiran-penafsiran ideologis terhadap teks. Mereka ingin menggeser sudut pandang ini. Demi tujuan ini, Arkoun mencoba membeberkan fakta bahwa kodifikasi al-Qur'an adalah tak lepas dari ijtihad manusia sebagai wacana tandingan atas pandangan yang terlampau mensakralkan mushaf Usmani. ${ }^{36}$ Rahman menuturkan bahwa al-Qur'an tidaklah hadir dalam ruang hampa budaya, akan tetapi sangat terkait erat dengan realitasnya. ${ }^{37}$ Abu Zayd juga menuturkan bahwa sebagai sebuah pesan, al-Qur'an pasti menggunakan kode yang dipahami oleh bangsa Arab kala itu agar pesannya tersampaikan. Al-Qur'an dengan demikian tidak serta merta turun dari langit. ${ }^{38}$ Buah pemikiran di atas tak lain merupakan sebuah upaya untuk menempatkan al-Qur'an pada posisinya yang 'seharusnya'.

Namun demikian, meskipun para sarjana di atas dan Neuwirth memiliki kegelisahan yang senada tentang status alQur'an yang hidup dan yang telah dikodifikasi, penulis melihat adanya perbedaan solusi. Solusi yang ditawarkan sarjana Muslim di atas umumnya adalah menerapkan metode tematik, ${ }^{39}$ yakni, penafsiran dengan berangkat dari tema tertentu dan menggali ayat-ayat dari seluruh surat dalam al-Qur'an yang berkenaan dengan tema tersebut. Asumsi dari metode ini, mengutip Rahman, adalah bahwa al-Qur'an adalah kitab yang koheren dan kohesif dengan slogan al-Qur'an yufassiruba'dubu ba'dan-nya. ${ }^{40} \mathrm{Di}$ sisi lain, menurut al-Khulli, pendekatan tematis ini penting

${ }^{36}$ Arkoun, Rethinking Islam..., 35-40.

${ }^{37}$ Lihat, Fazlur Rahman, Islam and Modernity: Transformation of an Intellectual Tradition (Chicago: The University of Chicago Press, 1984), 6.

${ }^{38}$ Lihat, Abu Zayd, Rethinking the Qur'an..., 9-18.

${ }^{39}$ Pengertian tematik yang penulis maksud di sini adalah pengertian umum, bukan maudu'i-nya Muhammad al-Ghazali yang didefinisikan sebagai tematis surat sebagaimana disebutkan dalam kitabnya Nabwa Tafsir alMaudu'i li Suwar al-Qur'an al-Karim (1995). Pengertian tafsir tematik yang dalam pembahasan kali ini dalam term al-Ghazali adalah al-Tafsir al-Maudu'i. Lihat, Nur Kholis Setiawan, Al-Qur'an Kitab Sastra Terbesar (Yogyakarta: Elsaq Press, 2005), 20.

${ }^{40}$ Rahman mengkonfrontasikan tafsir ini dengan tafsir yang atomistik dan parsial yang sebelumnya menjadi tren dalam tafsir al-Qur'an. Rahman, Islam and Modernity..., 2-4, dan 21. 
karena dengan tata dan urutan al-Qur'an yang seperti adanya sekarang, informasi al-Qur'an tentang tema tertentu tidak hanya ada dalam satu surat saja akan tetapi bertebaran di banyak surat. ${ }^{41}$ Mereka menganggap metode ini sebagai yang paling komprehensif, holistik, total, dan tidak atomistis ataupun parsial dalam memahami al-Qur'an seperti dalam metode tablilit. 42

Berbeda dari itu, tawaran Neuwirth adalah dengan mendasarkan penafsiran berbasis surat. Pilihan surat sebagai titik berangkat adalah sesuatu yang sangat prinsipil dalam pembacaan Neuwirth, karena dia adalah unit tuturan yang digunakan pada masa Nabi. Surat, dengan demikian, adalah pintu gerbang kepada al-Qur'an yang 'hidup', sesuatu yang dituju oleh pembacaan pra-kanonisasi ini. Surat itu kemudian dilihat dalam kerangka tartīb nuzüli sehingga gambaran perjalanan surat tersebut dalam perkembangan kanon dan dakwah Nabi menjadi jelas. Dengan demikian, kronologisasi al-Qur'an adalah sesuatu yang urgen dalam mengkaji al-Qur'an. Dia akan memberikan gambaran utuh perjalanan al-Qur'an dan pertumbuhan komunitas Nabi.

Dalam kesarjanaan Muslim kontemporer, terdapat pula kesadaran akan pentingnya membaca al-Qur'an dalam kerangka kronologinya. Salah satunya yang disampaikan oleh 'Abīd alJābirī. ${ }^{43}$ Penulis menemukan kedekatan metodis dalam kedua tokoh ini, meskipun keduanya berangkat dari kegelisahan epistemologis yang berbeda. Tujuan tafsir al-Jābirī dengan memilih model tahliti nu₹ūit adalah juga untuk meringkas pemahaman al-Qur'an sesuai dengan orisinalitas al-Qur'an (asālah al-nas). ${ }^{44}$ Selain itu, Neuwirth dan al-Jābirī berangkat dari pandangan yang sama bahwa pemahaman al-Qur'an tidaklah berangkat dari al-Qur'an yang telah dikodifikasi sebagai mushaf, akan tetapi pemahaman al-Qur'an haruslah berangkat dari al-

${ }^{41}$ Nur Kholis, Al-Qur'an Kitab..., 19.

${ }^{42}$ Moch. Nur Ichwan, Hermeneutika al-Qur'an: Analisis Peta Perkembangan Metodologi Tafsir al-Qur'an Kontemporer, Skripsi (IAIN Sunan Kalijaga, 1995), 150.

${ }^{43} \mathrm{Al}-\mathrm{Jābir} \overline{1}$ telah menghasilkan tiga volume karya tafsir yang berbasis surat dalam urutan kronologisnya yang diterbitkan pada tahun 2008 dan 2009, yakni Fahm al-Qur'àn al-Hakim: Tafsì al-W adīh Hasb Tartīb al-Nuzūl.

${ }^{44}$ Al-Jābirī, Fahm al-Qur'ān al-Hakìm, volume 1, 10. 
Qur'an ketika dia hidup pada masa Nabi, dengan tetap berpijak kepada al-Qur'an yang ada sekarang. Karenanya, keduanya sangat tertarik kepada tartīb nu₹ülì al-Qur'an. Kesamaan kedua dari kedua tokoh ini adalah gagasan keduanya bahwa pertumbuhan al-Qur'an itu sangatlah seiring sejalan dengan perkembangan dakwah Nabi, dan itu tercermin dalam cara teks menuturkan dirinya_dalam bahasa al-Jābirī, logika siyāq. Dalam bahasa Neuwirth the growth of canon sejalan dengan the emergence of community dan dalam bahasa al-Jābirī, masār al-tanæīl sejalan dengan masirät al-da'wäh, ${ }^{45}$ yang pada akhirnya mereka jadikan sebagai prinsip dalam membuat analisisnya teradap teks alQur'an.

\section{Catatan Akhir}

Kesarjanaan al-Qur'an kontemporer di Barat telah mengalami pergeseran menjadi lebih akademis-dialogis sejak tahun 1980-an yang salah satunya ditandai dengan lahirnya karya disertasi Angelika Neuwirth. Pergeseran ini muncul karena mulai digunakannya pendekatan sastra dalam mengkaji al-Qur'an. Dengan pendekatan tersebut, ditambah dengan pendekatan historis, Neuwirth memberikan sebuah tawaran untuk pembacaan pra-kanoniasi al-Qur'an, yakni pembacaan yang menggali sepak terjang al-Qur'an pada masa turunnya. Tawaran ini berangkat dari kegelisahan adanya dehistorisasi al-Qur'an pasca kodifikasi. Ketika sudah didudukkan bersama sarjanasarjana Muslim yang memiliki kegelisahan yang sama, terlihat dua cara yang berbeda dalam menjawab kegelisahan yang sama. Pertama, tafsir tematik. Kedua, yakni metode Neuwirth, dengan analisis struktur mikro satuan unit surat. Dua metode yang berbeda ini semakin memberikan keragaman metode dalam kesarjanaan al-Qur'an, khususnya kontemporer. Wa al-Läh a'lam bi al-sawāb.

\section{Daftar Pustaka}

Abu Zayd, Nasr Hamid. 2004. Rethinking the Qur'an: Towards a Humanistic Hermeneutics. Amsterdam: Humanistics University Press.

${ }^{45}$ Ibid., 9-18. 
Arkoun, Mohammed. 1994. Rethinking Islam: Common Questions, Uncommon Answer, ter. Robert D. Lee, Boulder. San Fransisco dan Oxford: Westview Press.

Boullata, Issa J. (ed.). 2000. Literary Stuctures of Religious Meaning in the Qur'an. Richmond: Curzon Press.

Ichwan, Moch. Nur. 1995. Hermeneutika al-Qur'an: Analisis Peta Perkembangan Metodologi Tafsir al-Qur'an Kontemporer, Skripsi. IAIN Sunan Kalijaga.

Al-Jābirī, Muḥammad 'Abīd. 2006. Madkhal ilā al-Qur'ān al-Karim: al-Juz' 'ul Awwal fì al-Ta'rif bi al-Qur'ān. Beirut: Markaz Dirāsāt al-Wiḥdah al-'Arabiyah.

Madigan, Daniel A. 1995. "Reflections on Some Current Directions in Qur'anic Studies", The Muslim World, volume LXXXV, number 3-4.

McAuliffe, Jane Dammen. 2001. "Preface" dalam Encyclopaedia of the Qur'an, ed. Jane D. McAuliffe. Leiden: E. J. Brill, volume 1.

Nafatu Fina, Lien Iffah. 2001. Pe-Canonical Reading of the Qur'an: Studi atas Metode Angelika Neuwirth dalam Analisis Teks alQur'an Berbasis Surat dan Intertekstualitas, Thesis. Yogyakarta: PPs UIN Sunan Kalijaga.

Neuwirth, Angelika. 1993. "Images and Metaphors in the Introductory Section of the Meccan suras" dalam Approaches to the Qur'an, ed. G. R. Hawting dan Abdul-Kader A. Shareef. London dan New York: Routledge.

. 1996. "Von Rezitationstext uber die liturgie zum

Kanon: Zu Entstehung und Wiederauflosung der Surenkomposition im Verlauf der Entwicklung eines Islamischen Kultus" dalam The Qur'an as Text, ed. Stefan Wild. London: E. J. Brill.

. 2000. "Referentiality and Textuality in Surat al-

Hijr: Some Observations on the Qur'anic "Canonical process" and the Emergence of a Community" dalam Literary Stuctures of Religious Meaning in the Qur'an, ed. Issa J. Boullata. Richmond: Curzon Press. . 2002. "Form and Structure of the Qur'an" dalam

Encyclopaedia of the Qur'an, volume 2, ed. Jane D. McAuliffe.

Leiden: E. J. Brill. 
. 2003. “Qur'an and History - a Disputed

Relationship: Some Reflections on Qur'anic History in the Qur'an" dalam Journal of Qur'anic Studies.

- 2006. "Structure and the Emergence of

Community" dalam The Blackwell Companion to the Qur'an, ed.

Andrew Rippin. Oxford: Blackwell Publishing.

. 2007. "Orientalism in Oriental Studies? Qur'anic

Studies in Case", Journal of Qur'anic Studies, volume IX, Issue

2.

Liturgy, Hellenic Rhetoric and Arabic Language", Public Lecture,3 Juni 2009 di West Building Lecture Hall at the Institute for Advanced Study. www. ias. edu.

. 2010. "Qur'anic Reading of the Psalms" dalam The

Qur'an in Context: Historical and Literary Investigations into the

Qur'anic Milieu, ed. Angelika Neuwirth, Nicolai Sinai dan Michael Marx. London: E. J. Brill.

. 2010. "Two Faces of the Qur'an: Qur'an and Mushaf', Oral Tradition, volume 25, Issue 1 (Maret).

Neuwirth, Angelika dan Nicolai Sinai. 2010. "Introduction" dalam The Qur'an in Context: Historical and Literary Investigations into the Qur'anic Milieu, ed. Angelika Neuwirth, Nicolai Sinai dan Michael Marx. London: E. J. Brill.

Neuwirth, Angelika dan Michael Marx, "Corpus Coranicum:

Exploring the Textual Beginnings of the Qur'an", Scientific Report, Berlin, 6-9 November 2005, http://www. esf. org $/$ index.php?eID $=$ tx_nawsecuredl\&u $=0 \&$ file $=$ fileadmin $/$ be_user/ew_docs/04-187_Report.

pdf\&t $=1287616018 \&$ hash $=$ b3bbd232ec $975721 \mathrm{fb} 9 \mathrm{bc} 4535 \mathrm{~d}$ e878d7, akses tanggal 23 oktober 2010.

Rahman, Fazlur. 1984. Islam and Modernity: Transformation of an Intellectual Tradition. Chicago: The University of Chicago Press.

Rippin, Andrew. 1982. "Book Review: Studien zur Komposition der Mekekanischen Suren by Angelika Neuwirth", Bulletin of the School of Oriental and African Studies, volume 45, number 1.

Robinson, Neal. 1996. Discovering the Qur'an: a Contemporary Approaches to a Veiled Text. London: SCM Press. 
2000. "The Structure and Interpretation of Surat alMukminun", Journal of Qur'anic Studies, volume II, Issue I.

Setiawan, Nur Kholis. 2005. Al-Qur'an Kitab Sastra Terbesar. Yogyakarta: Elsaq Press.

Wild, Stefan. 1996. "Preface", dalam The Qur'an as Text, ed. Stafan Wild. London: E. J. Brill. 